\title{
Analisis Determinan Perilaku Pemeriksaan Payudara Sendiri (SADARI) pada Mahasiswi Fakultas Kesehatan Masyarakat Universitas Muhammadiyah Jakarta
}

\author{
Istianah Surury, Astri K Sari, Sari Rahmadhayanti , Siti A Permatasari \\ Prodi S1 Kesehatan Masyarakat, Fakultas Kesehatan Masyarakat, Universitas \\ Muhammadiyah Jakarta
}

\begin{abstract}
Abstrak
Latar Belakang: Deteksi stadium awal adalah salah satu cara untuk mencegah kanker payudara. Periksa payudara sendiri (SADARI) adalah metode pemeriksaan dini pada kanker stadium awal yang bisa dilakukan secara mandiri. Meskipun demikian, ternyata kebiasaan tersebut belum banyak dilakukan perempuan Indonesia. Kurang diterapkannya kebiasaan tersebut dalam keseharian menjadi salah satu penyebab tidak langsung pada kematian kanker payudara yang berhubungan dengan keterlambatan diagnosis. Penelitian ini dilakukan untuk mengetahui faktor determinan yang berhubungan dengan perilaku pemeriksaan payudara sendiri (SADARI) pada mahasiswi Fakultas Kesehatan Masyarakat Universitas Muhammadiyah Jakarta.

Metode: penelitian ini mengunakan desain studi cross-sectoonal pada Desember 2019- Januari 2020. Sebanyak 83 mahasiswi menjadi responden dengan mengisi kuesioner daring melalui google form. Variabel yang diteliti adalah usia, riwayat keluarga, pengetahuan, sikap dan perilaku SADARI. Data dianalisis menggunakan uji chi square

Hasil: Ditemukan perbedaan yang signifikan antara sikap dengan perilaku SADARI ( $p=0,015$ dan OR=3,744 (95\% CI= 1,38-10,14)). Tidak ditemukan adanya perbedaan yang bermakna antara riwayat keluarga dan pengetahuan dengan perilaku SADARI pada mahasiwi.

Kesimpulan: Edukasi yang diberikan di kampus dapat diimplementasikan oleh mahasiwi dengan menanamkan sikap positif dan menerapkannya dalam kehidupan sehari-hari. Sehingga terwujud budaya SADARI yang tinggi pada mahasiswi dan menjadi contoh bagi mahasiswi non kesehatan lainnya di lingkungan UMJ maupun orangorang di sekitar.
\end{abstract}

Kata Kunci: Kanker Payudara, Pengetahuan, Perilaku, SADARI, Sikap

\section{Analysis of Determinant Breast Self-Examination (BSE) Behavior in Students of Faculty of Public Health University of Muhammadiyah Jakarta}

\begin{abstract}
Background: Early stage detection is one of ways to prevent breast cancer. Breast self-examination (SADARI) is an early screening method for early stage cancer that can be done independently. Nevertheless, it turns out that the habit has not been done much by Indonesian women. The lack of daily use of the habit is one of the indirect causes of breast cancer deaths associated with delays in diagnosis. This research was conducted to determine determinants related to the breast self-examination behavior (BSE) in students of Faculty of Public Health, Muhammadiyah University Jakarta.

Methods: This study used cross-sectional study design during December 2019-January 2020. A total of 83 studies became respondents by filling in an online questionnaire through a Google form. Collected variables were age, family history, knowledge, attitudes, and BSE behavior. Data analysed using chi square test.

Results: There was significant differences between attitudes and BSE $(p=0,015$ and OR = 3,744 $(95 \%$ CI $=1.38$ 10.14)). No significant differences were found between family history and knowledge with BSE in students.

Conclusion: Preventive education provided on campus can be implemented by students by instilling a positive attitude and applying it in everyday life. Related to the realization of higher BSE culture and become an example for other non-health students in the UMJ environment as well as those around.
\end{abstract}

Keywords: BSE, Knowledge, Attitude, Behavior, Breast Cancer

\author{
Alamat korespondensi: \\ Istianah Surury \\ Fakultas Kesehatan Masyarakat \\ Universitas Muhammadiyah Jakarta \\ Email : istianah.surury@umj.ac.id
}




\section{PENDAHULUAN}

Fenomena transisi epidemiologi sudah terjadi dalam beberapa dekade terakhir. Angka kematian akibat penyakit tidak menular, termasuk kanker, di Indonesia semakin meningkat. Hal ini berkaitan dengan semakin meningkatnya jumlah penderita kanker di Indonesia, salah satunya adalah kanker payudara. ${ }^{1}$

Kanker payudara merupakan tumor ganas pada kelenjar, saluran kelenjar dan jaringan penunjang payudara. Penyakit ini merupakan penyumbang kematian pada perempuan, oleh karena itu kanker payudara menjadi salah satu yang paling ditakuti perempuan. $^{2}$ Kanker ini ditandai dengan munculnya sekelompok sel abnormal yang perlahan-lahan tumbuh menjadi benjolan di payudara. ${ }^{3}$

Berdasarkan data Globocan, International Agency for Research on Cancer (IARC) tahun 2018, kanker payudara dengan kasus baru sebanyak 2.088.849 (5,03 \%) kasus dan kematian akibat kanker payudara sebanyak $626.679(1,41 \%)$ kasus pada perempuan di dunia. ${ }^{4}$ Sedangkan di Indonesia kanker payudara berada di posisi pertama pada kejadian kanker lainya dengan kasus baru tertinggi sebanyak 58. $256(30,9 \%)$ kasus dan menjadi penyumbang angka kematian tertinggi ke-2 setelah kanker paru yaitu sebanyak $22.692(11,0 \%)^{5}$

Upaya untuk mencegah kanker payudara diutamakan pada deteksi dini tahap awal kanker. Salah satu cara deteksi dini tersebut adalah periksa payudara sendiri (SADARI). Semakin dini dilakukan SADARI, maka akan semakin efektif. Cara melakukan SADARI adalah pada hari ke-7 sampai dengan hari ke-10 sejak hari pertama haid. Pada masa ini kadar hormone estrogen dan progesterone sedang mencapai titik terrendah sehingga tidak membuat jaringan dan kelenjar payudara membengkak yang memudahkan perempuan untuk meraba adanya benjolan abnormal pada payudara. ${ }^{6}$

Tata cara SADARI yang mudah dan besar manfaatnya tidak menjadi jaminan perilaku tersebut dipraktikkan oleh perempuan Indonesia. Nyatanya masih banyak perempuan Indonesia yang belum membiasakan perilaku tersebut. Kurangnya penerapan SADARI menjadi pemicu tidak langsung terhadap keterlambatan diagnosis dan penangan medis serta tingginya angka kematian akibat kanker payudara

Perempuan yang memiliki riwayat keluarga yang menderita kanker payudara akan lebih berisiko untuk terkena kanker payudara di kemudian hari dibandingkan yang tidak memiliki riwayat keluarga. ${ }^{7}$ Usia yang paling tepat untuk mencegah kanker payudara sejak dini adalah usia remaja. Fakultas Kesehatan Masyarakat Universitas Muhammadiyah Jakarta merupakan institusi yang mayoritas mahasiswanya berjenis kelamin perempuan. Oleh karena itu penelitian ini dilakukan untuk mengetahui faktor determinan yang berhubungan dengan perilaku pemeriksaan payudara sendiri (SADARI) pada mahasiswi Fakultas Kesehatan Masyarakat Universitas Muhammadiyah Jakarta.

\section{METODE}

Penelitian ini menggunakan pendekatan kuantitatif analitik dengan desain studi cross-sectional yang mana pengukuran varibel dilakukan pada satu saat yang bersamaan. Penelitian ini dilakukan pada bulan Desember 2019-Januari 2020. Populasi dalam penelitian ini adalah seluruh Mahasiswi Fakultas Kesehatan Masyarakat. Berdasarkan perhitungan, menggunakan rumus uji beda dua proporsi didapatkan jumlah sampel minimal dalam penelitian ini adalah sebanyak 74,96 yang dibulatkan menjadi 75 orang ditambahkan $10 \%$ dari jumlah sampel minimal untuk menghindari missing data menjadi 83 orang. Teknik sampling menggunakan purposive sampling. Sampel dipilih dengan mempertimbangkan kriteria inklusi berupa mahasiswa perempuan yang aktif di program studi S1 Kesehatan Masyarakat Fakultas Kesehatan Masyarakat Universitas Muhammadiyah Jakarta, sudah menstruasi, serta bersedia menjadi responden. Pengumpulan data dilakukan dengan cara mengisi kuesioner daring menggunakan aplikasi google form. Analisis data dalam peneiltian ini menggunakan analisis univariat dan bivariat dengan chi-square.

\section{HASIL}

\section{Analisis Univariat}

Penelitian ini dilakukan pada responden yang berusia 18-23 tahun. 
Kategori responden tersebut merupakan kelompok usia remaja akhir-dewasa muda. Berdasarkan riwayat keluarga dengan kanker payudara terdapat 76 responden $(91,6 \%)$ sedangkan berdasarkan pengetahuan mahasiswi tentang SADARI adalah sebanyak 54 $(65,1 \%)$ mahasiswi dengan kategori baik pengetahuannya dan sebanyak 29 $(34,9 \%)$ mahasiswi dengan kategori pengetahuan kurang.

\section{Tabel 1. Rekapitulasi Analisis Univariat}

\begin{tabular}{|c|c|c|}
\hline Variabel & Jumlah & Persentase \\
\hline Riwayat keluarga & & \\
\hline Ada & 7 & 8,4 \\
\hline Tidak ada & 76 & 91,6 \\
\hline Pengetahuan & & \\
\hline Baik & 54 & 65,1 \\
\hline Kurang & 29 & 34,9 \\
\hline Sikap & & \\
\hline Positif & 58 & 69,9 \\
\hline Negatif & 25 & 30,1 \\
\hline Perilaku & & \\
\hline Sadari & 45 & 54,2 \\
\hline Tidak sadari & 38 & 45,8 \\
\hline
\end{tabular}

Sikap mahasiswi tentang SADARI sendiri pada penelitian ini sebanyak $58(69,9 \%)$ dengan kategori

positif dan sebanyak $25 \quad(30,1 \%)$ mahasiswi dengan kategori sikap negatif. Selain itu, diperoleh $45 \quad(52,2 \%)$ mahasiswi yang pernah dan telah melakukan SADARI dan sebanyak 38 $(45,8 \%)$ mahasiswi yang tidak melakukan SADARI.

\section{Analisis Bivariat}

Penelitian ini menghasilkan 2 jenis hubungan yang berbeda pada 3 variabel utama yang diteliti. Pada 28,6\% mahasiswi yang memiliki riwayat keluarga dengan kanker payudara telah berperilaku SADARI, dan 56,6\% yang tidak memiliki riwayat keluarga dengan kanker payudara pun telah berperilaku SADARI. Didapatkan nilai $P 0,238$ yang berarti tidak ada perbedaan yang signifikan terhadap perilaku SADARI pada mahasiswi yang memiliki riwayat keluarga dengan kanker payudara maupun yang tidak memiliki.

Tabel 2. Rekapitulasi Analisis Bivariat

\begin{tabular}{|c|c|c|c|c|c|c|c|c|c|c|}
\hline \multirow{2}{*}{\multicolumn{2}{|c|}{ Variabel }} & \multicolumn{4}{|c|}{ Sadari } & \multirow{2}{*}{\multicolumn{2}{|c|}{ Total }} & \multirow{3}{*}{$\begin{array}{c}\text { Nilai } \\
P\end{array}$} & \multirow[t]{3}{*}{ OR } & \multirow[t]{3}{*}{$95 \% \mathrm{CI}$} \\
\hline & & \multicolumn{2}{|c|}{ Ya } & \multicolumn{2}{|c|}{ Tidak } & & & & & \\
\hline & Kategori & $\mathbf{n}$ & $\%$ & $\mathbf{n}$ & $\%$ & $\mathbf{n}$ & $\%$ & & & \\
\hline \multirow[t]{2}{*}{ Riwayat keluarga } & Ada & 2 & 28,6 & 5 & 71,4 & 7 & 100 & 0,238 & & \\
\hline & Tidak ada & 43 & 56,6 & 33 & 43,4 & 76 & 100 & & & \\
\hline \multirow[t]{2}{*}{ Pengetahuan } & Baik & 28 & 51,9 & 26 & 48,1 & 54 & 100 & 0,720 & & \\
\hline & Kurang & 17 & 58,6 & 12 & 41,4 & 29 & 100 & & & \\
\hline \multirow[t]{2}{*}{ Sikap } & Positif & 37 & 63,8 & 21 & 36,2 & 58 & 100 & 0,015 & 3,744 & $1,38-10,14$ \\
\hline & Negatif & 8 & 32,8 & 17 & 68,0 & 83 & 100 & & & \\
\hline
\end{tabular}

Hal yang serupa juga terlihat pada variabel pengetahuan. Terdapat $51,9 \%$ mahasiswi yang berpengetahuan baik yang berperilaku SADARI dan 58,6\% dari mereka yang berpengetahuan kurang baik pun berperilaku SADARI. Nilai $P$ menghasilkan 0,720 yang berarti tidak ada perbedaan yang signifikan antara mahasiswi yang berpengetahuan baik maupun yang berpengetahuan kurang terhadap perilaku SADARI.

Hasil yang berbeda terlihat pada variabel sikap. Terdapat $63,8 \%$ mahasiswi yang bersikap positif dan berperilaku SADARI. Sedangkan hanya $32,8 \%$ yang berperilaku SADARI pada mereka yang bersikap negatif. Kemudian didapatkan nilai $P$ sebesar 0,015 yang berarti ada perbedaan yang signifikan antara mahasiswi yang bersikap positif dan yang bersikap negatif terhadap perilaku SADARI. Didapatkan nilai OR 3,744 yang berarti odds pada responden yang bersikap positif 3,744 kali lebih besar dibandingkan odds pada mereka yang bersikap negatif untuk berperilaku SADARI. 


\section{PEMBAHASAN}

1. Analisis Univariat

Penelitian ini dilakukan pada remaja dengan usia 18-23 yang dimana umur mempengaruhi tingkat pengetahuan. Semakin bertambah umur semakin bertambah pula dan pengetahuan seseorang yang diperolehnya. Menurut pada usia 20 tahun, kesadaran dan penalaran yang baik mempengaruhi usia remaja ini. Pesatnya kemajuan teknologi informasi baik media cetak maupun media elektronika berperan penting dalam menentukan tingkat pengetahuan remaja, sehingga semakin banyak informasi yang didapat semakin berwawasan luas. Selain itu, umur juga menjadi factor penentu dalam proses perkembangan mental. ${ }^{8}$

Hasil penelitian mengenai tingkat pengetahuan tentang SADARI pada mahasiswi Fakultas Kesehatan Masyarakat Universitas Muhammadiyah Jakarta diperoleh hasil mahasiswi sebagian besar dengan pengetahuan yang baik tentang kanker payudara. Hal ini memiliki hasil yang serupa dengan hasil riset pada wanita usia subur (WUS) di Kelurahan Nunu Kecamatan Tatanga menunjukan sebagian besar responden dengan pengetahuan baik yaitu 93 $(98,9 \%)$, pengetahuan cukup $1(1,1 \%)$

dan pengetahuan kurang $0 \quad(0 \%)$ responden. ${ }^{9}$

Faktor lingkungan dan sumber informasi dengan memberikan edukasi merupakan salah satu faktor yang berkaitan dengan tingkat pengetahuan. Edukasi dengan sumber informasi berupa leaflet, video SADARI, dan media patung tentang pengertian dan stadium pada kanker payudara, gejala dan tanda kanker payudara, faktor resiko kanker payudara, pengertian dan cara melakukan SADARI, manfaat SADARI terbukti berhubungan dengan peningkatan pengetahuan tentang SADARI. ${ }^{10}$ Penelitian ini dilakukan pada mahasiswi Fakultas Kesehatan Masyarakat yang dimana responden sudah banyak mengetahui informasi tentang kesehatan. Rentang usia remaja yang dimaksud juga merupakan kelompok usia terbanyak yang mengakses sumber informasi dari berbagai media, terutama media daring.
Hasil penelitian mengenai sikap tentang SADARI pada mahasiswi Fakultas Kesehatan Masyarakat Universitas Muhammadiyah Jakarta diperoleh hasil mahasiswi sebagian besar dengan sikap positif. Hasil ini serupa dengan temuan Patandianan dkk pada wanita usia subur (WUS) di Kelurahan Nunu Kecamatan Tatanga menunjukan sebanyak $90(95,7 \%)$ responden bersikap positif dan $4(4,3 \%)$ respoden bersikap negatif. Sikap positif responden dalam penelitian ini dikarenakan responden mengetahui bahwa SADARI bermanfaat untuk mendeteksi sendiri kanker payudara pada perempuan sedini mungkin. Selain itu, keluarga merupakan pusat informasi pertama dalam menjaga kesehatan sehingga responden dapat memperoleh perilaku yang dapat mencegah penyakit. Lingkungan sosial, terutama orang-orang terdekat yang ada di sekitar kita merupakan bagian penting yang dapat mempengaruhi sikap kita. ${ }^{9}$

Hasil penelitian mengenai perilaku tentang SADARI pada mahasiswi Fakultas Kesehatan Masyarakat Universitas Muhammadiyah Jakarta diperoleh lebih dari setengah total responden mahasiswi telah berperilaku sadari. Hal ini serupa dengan hasil riset Patandianan dkk pada wanita usia subur (WUS) di Kelurahan Nunu Kecamatan Tatanga menunjukan perilaku melakukan SADARI sebanyak $59(62,6 \%)$ responden dan perilaku tidak melakukan SADARI sebanyak $35(37,2 \%)$ responden ${ }^{9}$.

\section{Analisis Bivarat}

a. Hubungan Riwayat Keluarga dengan Perilaku SADARI

Hasil uji bivariat menunjukkan tidak ada hubungan yang signifikan antara riwayat keluarga dengan perilaku SADARI pada mahasiswi. Hal ini secara sekilas bertentangan dengan teori yang ada. Seseorang yang memiliki riwayat keluarga dengan kanker payudara seharusnya lebih peduli untuk berperilaku SADARI karena takut hal yang sama menimpa dirinya. ${ }^{8}$ Namun hasil dalam penelitian ini berbeda karena jumlah mereka yang memiliki riwayat keluarga 
dengan kanker payudara cenderung sedikit. Sehingga mempengaruhi hasil uji statistik. Hasil yang serupa juga didapatkan oleh Khairunnisa dkk dalam penelitiannya yang dilakukan pada mahasiswi, bahwa tidak terdapat hubungan antara riwayat penyakit keluarga dengan perilaku SADARI. ${ }^{11}$

\section{b. Hubungan pengetahuan dengan perilaku SADARI}

Hasil penelitian menyatakan bahwa tidak terdapat hubungan pengetahuan dengan perilaku pada mahasiswi tentang SADARI. Penelitian ini tidak sejalan dengan penelitian yang dilakukan oleh Puspita pada mahasiswa non kesehatan di Universitas Hasanuddin yang menunjukan ada hubungan antara tingkat pengetahuan responden dengan perilaku melakukan SADARI $\mathrm{p}$ value $=0,000 \cdot{ }^{12}$ hasil serupa juga dibuktikan oleh Hemas bahwa ada perbedaan antara mereka yang berpengetahuan baik, cukup maupun kurang terhadap perilaku SADARI. ${ }^{13}$ \begin{tabular}{llr}
\multicolumn{2}{c}{ Perbedaan hasil yang } \\
ditemukan pada penelitian ini \\
dibandingkan penelitian lain
\end{tabular} kemungkinan terjadi karena proporsi yang berperilaku SADARI pada mahasiswi yang berpengetahuan baik dan kurang hampir sama. Menurut Notoatmodjo segala sesuatu yang kita ketahui tentang cara menjaga kesehatan merupakan pengertian dari pengetahuan kesehatan. Perilaku baru akan terbentuk jika didasari pengetahuan, kesadaran dan sikap yang positif. Jika hal tersebut terjadi, maka akan cenderung bertahan lama pada diri seseorang. ${ }^{14}$ Berdasarkan teori tersebut, pengetahuan hanyalah salah satu faktor yang mempengaruhi perilaku seseorang, tapi diiringi dengan kesadaran dan sikap yang positif, maka aspek-aspek tersebut saling bersinergi membentuk sebuah perilaku.

\section{c. Hubungan sikap dengan perilaku} SADARI

Perilaku seseorang didasari oleh sikap yang mendukung. ${ }^{15}$ Pada hasil penelitian, responden memiliki sikap positif dalam melakukan SADARI dan selebihnya hanya melakukan perabaan biasa dan tidak sesuai dengan teknik yang benar. Hal ini dikarenakan kurangnya kesadaran dan kemauan dari responden untuk melakukan SADARI. Hasil penelitian mendapatkan bahwa terdapat hubungan sikap dengan perilaku pada mahasiswi tentang SADARI $p$ value $=$ $0,015(\mathrm{p}=\alpha<0,05)$. Penelitian ini serupa dengan hasil riset Puspita (2016) pada mahasiswa non kesehatan di Universitas Hasanuddin yang menunjukan ada hubungan antara tingkat pengetahuan responden dengan perilaku melakukan SADARI $p$ value $=0,000(\mathrm{p}=\alpha<0,05)^{11}$.

Sikap yang ditanyakan dalam kuesioner penelitian ini meliputi sikap positif dan negatif terhadap perilaku SADARI. Setiap responden diminta untuk menjawab dengan skala likert dengan 4 rentang yaitu sangat setuju hingga sangat tidak setuju. Mahasiswi yang bersikap positif cenderung lebih banyak yang melakukan SADARI dibandingkan yang bersikap negatif. Cerminan sikap ada pada perilaku. Sikap memperkuat perilaku yang merupakan perwujudan dari pengetahuan yang baik dan kesadaran akan pentingnya perilaku tersebut ${ }^{13}$.

\section{SIMPULAN}

Karakteristik mahasiswi yang menjadi responden dalam peneltian ini adalah usia 1823 tahun yang merupakan rentang usai remaja menuju dewasa muda. Mayoritas responden tidak memiliki riwayat keluarga dengan kanker payudara. Pengetahuan responden akan SADARI cenderung baik. Responden yang bersikap positif lebih banyak dibandingkan yang bersikap negatif terhadap SADARI. Hasil-hasil tersebut bermuara pada perilaku SADARI yang sudah diterapkan oleh lebih dari setengah total responden.

Hasil uji dua variabel menyatakan tidak ada perbedaan yang signifikan antara riwayat keluarga dan pengetahuan dengan perilaku SADARI. Sedangkan ditemukan perbedaan yang signifikan pada sikap mahasiswi terhadap perilaku SADARI. Mereka yang bersikap positif cenderung melakukan SADARI dibandingkan yang bersikap negatif (nilai $\mathrm{P}=0,015$ ) dengan didapatkan nilai $\mathrm{OR}$ 3,744 yang berarti odds pada responden yang bersikap positif 3,744 kali lebih besar 
dibandingkan odds pada mereka yang bersikap negatif untuk berperilaku SADARI.

Namun perlu dilakukan peningkatan perilaku SADARI pada mahasiswi FKM UMJ. Mahasiswi kesehatan seharusnya bisa lebih sadar untuk berperilaku sehat dan mengutamakan aspek pencegahan. Edukasi yang diberikan di kampus dapat diimplementasikan oleh mahasiwi dengan menanamkan sikap positif dan menerapkannya dalam kehidupan sehari-hari. Antar mahasiswi juga bisa saling mendukung dan mengajak satu-sama lain. Sehingga terwujud budaya SADARI yang tinggi pada mahasiswi dan menjadi contoh bagi mahasiswi non kesehatan lainnya di lingkungan UMJ maupun orangorang di sekitar.

\section{DAFTAR PUSTAKA}

1. Yulinda A, Fitriyah N. Efektivitas Penyuluhan Metode Ceramah Dan Audiovisual Dalam Meningkatkan Pengetahuan Dan Sikap Tentang SADARI Di SMKN 5 Surabaya. J Promkes. 2018;6(2):116-28.

2. Olfah Y. Pengaruh Pelatihan Menggunakan Modul Tentang Kanker Payudara Terhadap Pengetahuan, Minat Dan Perilaku Dalam Melakukan Pemeriksaan Payudara Sendiri (Sadari) Pada Wanita Usia 20-40 Tahun Di Propinsi Daerah Istimewa YogyakartA (DIY). Vol. 2, Prosiding Seminar Nasional \& Internasional. 2014.

3. Yulianti I, Setyawan H, Sutiningsih D, Epidemiologi MP, Penyakit D, Fakultas $\mathrm{T}$, et al. FAKTOR-FAKTOR RISIKO KANKER PAYUDARA (Studi Kasus Pada Rumah Sakit Ken Saras Semarang). Vol. 4. 2016.

4. Global Cancer Observatory. 2019.

5. Indonesia: Fact Sheet 2018. 2018.

6. Arafah ABR, Notobroto HB. Faktor Yang Berhubungan dengan Perilaku Ibu Rumah Tangga Melakukan Pemeriksaan Payudara Sendiri (SADARI). Indones J Public Heal. 2018 Feb;12(2):143.
7. Komite Penanggulangan Kanker Nasional. Panduan penatalaksanaan kanker payudara. Jakarta: Kementerian Kesehatan Republik Indonesia; 2012.

8. Nasihah M, Rodliyatun S. Gambaran pengetahuan remaja putri tentang SADARI. J Midpro. 2013;1(1).

9. Elda R, Suarayasa K, Diana V, Tingkat A, Patandianan RE, Towidjojo VD, et al. Hubungan antara tingkat pengetahuan dan sikap dengan tindakan tentang pemeriksaan payudara sendiri (SADARI) pada wanita usia subur (WUS) di Kelurahan Nunu Kecamatan Tatanga. Vol. 2, Jurnal Ilmiah Kedokteran. 2015 Mar.

10. Pulungan RM, Hardy FR. Edukasi -Sadarill (Periksa Payudara Sendiri) Untuk Deteksi Dini Kanker Payudara Di Kelurahan Cipayung Kota Depok. Disem J Pengabdi Kpd Masy. 2020;2(1):47-52.

11. Khairunnissa A, Wahyuningsih $\mathrm{S}$. Faktor-faktor yang Berhubungan dengan Perilaku Pemeriksaan Payudara Sendiri (SADARI) pada Mahasiswi Fakultas Kedokteran Universitas Pembangunan Nasional -Veteran\| Jakarta, 2017. J Profesi Med J Kedokt dan Kesehat. 2018 May;11(2).

12. Data Jumlah Pasangan Usia Subur di DKI Jakarta Menurut Kabupaten/Kota di DKI Jakarta Tahun 2018 - Kumpulan data - data.jakarta.go.id.

13. Rifka Fatimah H. Faktor-faktor yang mempengaruhi perilaku deteksi dini kanker payudara dengan sadari pada wanita di Kecamatan Tegalrejo kota Yogyakarta. Politeknik Kesehatan Kementerian Kesehatan Yogyakarta; 2018.

14. Notoatmodjo S. Promosi kesehatan dan perilaku kesehatan. 2012;

15. Notoatmodjo S. Pendidikan dan perilaku kesehatan. Jakarta: Rhineka Cipta; 2003. 